\title{
Implementasi Permainan Tradisional dalam Mengembangkan Kecerdasan Emosional (Studi Kasus di SD Negeri 2 Kalapagunung)
}

\author{
Widia Indah Lestari ${ }^{1}$, Nunu Nurfirdaus ${ }^{2}$ \\ Pendidikan Guru Sekolah Dasar, STKIP Muhammadiyah Kuningan ${ }^{1}$ \\ nunu@upmk.ac.id
}

\section{Info Artiket}

\section{Sejarah Artikel:}

Diterima Bulan Januari, 2020 Dipublikasikan Februari, 2020

Keywords: Traditional Games, Emotional Intelligence

Permainan Tradisional, Kecerdasan Emosional

\section{Abstrak}

Tujuan dari penelitian ini adalah untuk mengetahui tentang implementasi permainan tradisional dalam mengembangkan kecerdasan emosional siswa di SD Negeri 2 Kalapagunung Kecamatan Kramatmulya Kabupaten Kuningan. Metode yang digunakan dalam penelitian ini adalah metode deskriptif kualitatif dengan metode purposive sampling. Narasumber pokok dalam penelitian ini adalah siswa 1 orang kelas I, 1 orang kelas II, 2 orang kelas III, 3 orang kelas IV, 2 orang kelas V, 1 orang kelas VI, 7 orang guru dan 1 kepala sekolah SD Negeri 2 Kalapagunung. Teknik pengumpulan data yaitu observasi, wawancara, dan dokumentasi. Hasil penelitian menunjukkan bahwa permainan tradisional sudah di terpakan di sekolah ini. Hal ini di dukung oleh program dan kebijakan kepala sekolah serta peran guruguru yang memperkenalkan permainan tradisional kepada siswa. Dalam memperkenalkan permainan tradisional kepada siswa, para guru menerapkan permainan tradisional dalam pembelajaran, selain itu saat jam istirahat atau dalam kegiatan ekstrakurikuler serta dalam kegiatan non formal. Secara garis besar, permainan tradisional yang sering di terapkan di sekolah tersebut seperti gobang sodor, egrang, bakiak, parengket-rengket jengkol memiliki dampak yang baik kepada siswa, dimana permainan tradisional mampu mengembangkan kecerdasan emosional siswa.

\section{Abstract}

The purpose of this study was to find out about the implementation of traditional games in developing emotional intelligence of students at SD Negeri 2 Kalapagunung, Kramatmulya District, Kuningan District. The method used in this research is descriptive qualitative method with purposive sampling method. The main resource persons in this study were 1 student in class I, 1 in class II, 2 in class III, 3 in class IV, 2 in class V, 1 in class VI, 7 teachers and 1 principal in Kalapagunung State Elementary School. Data collection techniques are observation, interviews, and documentation. The results of the study showed that traditional games had already been consumed in this school. This is supported by the programs and policies of the principal and the role of teachers who introduce traditional games to students. In introducing traditional games to students, teachers apply traditional games in learning, other than during recess or in extracurricular activities as well as in nonformal activities. Broadly speaking, traditional games that are often applied in schools such as gobang sodor, egrang, bakiak, parengketparengket jengkol sticks have a good impact on students, where traditional games are able to develop students' emotional intelligence

Alamat Korespondensi Email
: STKIP Muhammadiyah Kuningan : nunu@upmk.ac.id
ISSN 2541-6855 (Online)

ISSN 2541-0199 (Cetak) 


\section{Jurnal Lensa Pendas, Vol. 5 Nomor 2 , Tahun 2020, Hlm 8 - 14}

Widia Indah Lestari ${ }^{1}$, Nunu Nurfirdaus ${ }^{2}$

\section{PENDAHULUAN}

Dewasa ini berbagai permainan anak semakin berkembang mengikuti perkembangan jaman atau biasa kita sebut dengan sebutan permainan modern. Kini permainan tradisional sudah tergeser oleh permainan modern yang menjadikan anakanak sibuk dan asyik sendiri dengan dunia mereka, dimana dalam setiap harinya mereka hanya duduk di depan layar komputer atau pun gadget nya. Permasalahan tersebut tentunya akan menghambat perkembangan kecerdasan anak salah satunya kecerdasan sosial dan kecerdasan emosional anak. Jika permasalahan tersebut tidak di tindak lanjuti, maka anak akan cenderung individualis.. Roger C. S dkk dalam Andriani (2012:6) menjelaskan bahwa bermain adalah sebuah sarana yang dapat mengembangkan anak secara optimal. Sebab bermain berfungsi sebagai kekuatan, pengaruh terhadap perkembangan dan lewat bermain pula didapat pengalaman yang penting dalam dunia anak. Pendapat lain dari Gallahue dalam Andriani (2012:6) juga mengatakan bahwa bermain merupakan kebutuhan anak yang paling mendasar saat anak berinteraksi dengan dunia sekitarnya. Bermain adalah suatu aktivitas yang langsung dan spontan dilakukan seorang anak bersama orang lain atau menggunakan benda-benda di sekitarnya dengan senang, sukarela dan imajinatif serta dengan menggunakan perasaannya, tangan atau anggota tubuhnya. Rendahnya kecerdasan emosional seorang anak akan berpengaruh terhadap berkomunikasi dengan teman sebayanya, di mana anak yang memiliki kecerdasan yang rendah cenderung pemalu, kurang percaya diri, mudah tersinggung dan lain sebagainya. Hal tersebut menjadikan anak menarik diri dari lingkungannya dan enggan untuk bekerja sama, bersosialisasi dengan temannya Tidak semua anak memiliki kecerdasan emosional yang baik, tapi ada beberapa siswa yang memiliki ciri-ciri anak yang dalam perkembangan kecerdasan emosionalnya masih terbilang rendah, hal ini apabila anak memiliki sikap yang mudah tersinggung karena belum mampu mengontrol emosinya, hingga anak tersebut berkelahi dengan temannya. Maka dari itu peneliti tergugah untuk melakukan penelitian yang berkenaan dengan kecerdasan emosional anak melalui permainan tradisional, dimana dari beberapa teori yang sudah di paparkan bahwa permainan tradisional mampu mengembangkan berbagai aspek kecerdasan, salah satunya yaitu kecerdasan emosional. Berdasarkan latar belakang masalah tersebut penulis akan melakukan penelitian Implementasi Permainan Tradisional Dalam Mengembangkan Kecerdasan Emosional (Studi Kasus di SD Negeri 2 Kalapagunung)".

\section{METODE PENELITIAN}

Menjelaskan kronologis penelitian, meliputi desain penelitian, prosedur penelitian (dalam bentuk algoritma, Pseudocode atau lainnya), cara pengujian dan perolehan data. 


\section{Jurnal Lensa Pendas, Vol. 5 Nomor 2 , Tahun 2020, Hlm 8 - 14}

Widia Indah Lestari ${ }^{1}$, Nunu Nurfirdaus ${ }^{2}$

Uraian jalannya penelitian harus didukung referensi, sehingga penjelasannya dapat diterima secara ilmiah.

Penelitian ini menggunakan pendekatan kualitatif. Menurut Moleong (2007:9) penelitian kualitatif menggunakan metode kualitatif yaitu pengamatan, wawancara dan penelaahan dokumen. Metode kualitatif ini digunakan karena berbagai pertimbangan. Sugiyono (2015:15) mengemukakan bahwa metode kualitatif merupakan metode penelitian yang berlandaskan pada filsafat postpositivisme,digunakan untuk meneliti pada kondisi obyek ilmiah, (sebagai lawannya instrumen adalah eksperimen) dimana peneliti adalah sebagai instrumen kunci, pengambilan sampel sumber data dilakukan secara puposive dan snowball, teknik pengumpulan dengan trianggulasi (gabungan), analisis data bersifat induktif/kualitatif dan hasil penelitian kualitatif lebih menekankan makna dari pada generalisasi. Metode penelitian kualitatif sering disebut sebagai metode peneliitian naturalistik, karena penelitiannya dilakukan pada kondisi yang alamiah (natural setting.) Berdasarkan penjelasan tersebut, peneliti menyimpulkan bahwa penelitian ini dilakukan dengan menggunakan pendekatan kualitatif dan menggunakan jenis penelitian studi kasus tentang studi permainan tradisional dan perkembangan kecerdasan emosional siswa SD Negeri 2 kalapagunung. Menurut Bogdan dalam Sugiyono (2015:334) mengemukakan bahwa analisis data adalah proses mencari dan menyusun secara sistematis data yang diperoleh dari hasil wawancara, catatan lapangan, dan bahan-bahan lain, sehingga dapat mudah dipahami, dan temuannya dapat diinformasikan kepada orang lain. Analisis data dilakukan dengan mengorganisasi data, memilih mana yang penting dan yang akan dipelajari, dan membuat kesimpulan yang dapat diceritakan kepada orang lain. Analisis data yang digunakan mengacu pada konsep Miles dan Huberman dalam Sugiyono (2015:337) mengemukakan bahwa terdapat tiga macam aktivitas dalam analisis data yaitu, reduksi data, display data, conclusion drawing/Verification. Adapun langkah-langkah dalam analisis data dapat ditunjukkan pada gambar berikut.

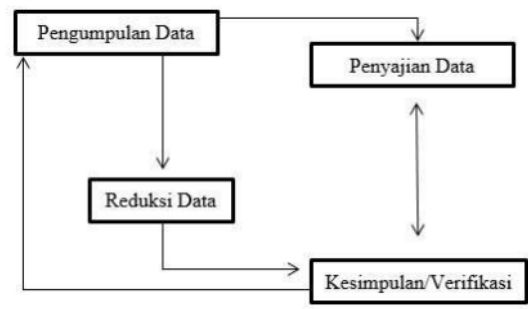

Gambar 1. Metode Penelitian

\section{HASIL PENELITIAN DAN PEMBAHASAN \\ 1. Permainan Tradisional \\ Adanya penelitian mengenai permainan tradisional yang dilakukan di sekolah ini mengingat bahwa perkembangan}




\section{Jurnal Lensa Pendas, Vol. 5 Nomor 2 , Tahun 2020, Hlm 8 - 14}

Widia Indah Lestari ${ }^{1}$, Nunu Nurfirdaus ${ }^{2}$

jaman yang semakin maju dan tidak bisa dipungkiri lagi bahwa permainan-permainan jaman dulu kini sudah mulai tergeser dengan permainan modern, dimana anakanak jaman sekarang kurang menyukai permainan tradisional dan jarang sekali memainkannya atau bahkan tidak tahu sama sekali. Meskipun terlihat sepele, namun permainan tradisional ini mengandung nilai-nilai tertentu yang dapat ditanamkan dalam diri anak tanpa mereka sadari, hal ini salah satu cara membiasakan anak pada berbagai interaksi dengan individu dan kelompok dalam masyarakat. Salah satu cara agar anak mengenal kembali permainan tradisional adalah dengan cara menggalakannya kembali dalam bentuk sebuah program atau kebijakan di sekolah, hal tersebut bertujuan untuk mengangkat kembali permainan tradisional yang sudah hampir punah agar tetap dikenal oleh anak-anak jaman sekarang. Mengenai hal tersebut berikut kutipan hasil wawancara dengan Bapak Abdul Rohman,S.Pd.I selaku kepala sekolah SD Negeri 2 Kalapagunung, beliau menuturkan: "Jadi terkait permainan tradisional sudah menjadi program dasar karena permainan tradisional membentuk karakter, harus menjadi satu model pembelajaran di sekolah dasar, dan hampir setiap tahun permainan tradisional itu selalu dilombakan dalam O2SN. Kalo untuk kebijakan sendiri sekarang ada waktu luang jadi waktu luang untuk sebelum atau setelah anak pulang sekolah ada waktu satu jam lebih. Jadi memang dianjurkan kepada guruguru untuk dimanfaatkan untuk eskul seperti permainan tradisional, terus untuk anak kelas 1 dan 2 biasanya di ajarkan calistung jadi segala kekurangan bisa diatasi dalam waktu tersebut. Untuk permainan tradisional sendiri kadang-kdang waktu istirahat, saat pelajaran olahraga ataupun proses belajar di kelas yang memang menunjang pembelajaran". Beliau juga mengutarakan bahwa: "Bisa dikatakan menjadi suatu keharusan karena permainan itu menjadi suatu alat untuk merubah sikap anak atau pun tingkat kecerdasan anak bisa diukur dari permainan tradisional bisa dijadikan alat ukur untuk mengetahui kecerdasan, keterampilan peserta didik".
Selain dari penuturan kepala sekolah, Ibu Elis Siti Mahmudah,S.Pd selaku guru wali kelas V, juga menuturkan: “.Iya ibu dan guru olahraga bekerja sama untuk memperkenalkan, mengajarkan permainan tradisional kepada anak, kebetulan kan ada programnya sekalian ada lomba nya juga jadi anak-anak itu dikenalkan, kalo ada waktu luang kita main di waktu istirahat ataupun setelah pulang sekolah sembari latihan juga". Selain dari petuturan kepala sekolah dan guru wali kelas $\mathrm{V}$, ada salah satu siswi bernama Tiara, dia merupakan salah satu siswi yang sangat menyukai permainan tradisional karena hobi, dia mengatakan: "Tau dari luar, tapi semenjak aku sekolah di sini diajarin juga sama guru. Kadangkadang teh, tapi kalo aku mah suka diajarin sama guru olah raga juga kalo mau lomba". Berdasarkan hasil wawancara diatas dapat disimpulkan bahwa di SD Negeri 2 kalapagunung ini memang ada permainan tradisional dan guru-guru juga menerapkan atau mengajarkan kepada anak sebagai bentuk pelestarian kebudayaan, hal ini di dukung oleh program kepala sekolah yang mengharuskan permainan tradisional ada di jenjang sekolah dasar guna membentuk karakter siswa. Permainan tradisional merupakan permainan yang mengandung nilai-nilai tertentu. Permainan tradisional sendiri memang banyak sekali jenisnya, mulai dari gobang sodor, engklek, congklak, lompat tali, egrang, bakiak dan lain sebaginya. Tiap daerah tentunya memiliki sebutan yang berbeda-beda, meskipun berbeda tapi cara memainkannya sama saja. Permainan tradisional yang ada di SD Negeri 2 Kalapagunung ini cukup banyak, hal ini terlihat dari keseharian anak dalam bermain di lingkungan sekolah pada saat jam istirahat ataupun di lingkungan tempat mereka tinggal.

\section{Implementasi Permainan Tradisional dalam Mengembangkan Kecerdasan Emosional}

Berdasarkan penelitian yang telah dilakukan maka didapatkan beberapa informasi mengenai implementasi permainan tradisional dalam mengembangkan kecerdasan emosional. Dalam proses pembelajaran tentunya guru 


\section{Jurnal Lensa Pendas, Vol. 5 Nomor 2 , Tahun 2020, Hlm 8 - 14}

Widia Indah Lestari ${ }^{1}$, Nunu Nurfirdaus ${ }^{2}$

tidak terlepas dari adanya model dan media pembelajaran yang digunakan untuk membantu proses pembelajaran agar lebih mudah. Untuk usia anak sekolah dasar pembelajaran yang menyenangkan tentu sangat diperlukan, dimana guru bisa mengajak anak belajar sambil bermain salah satunya dengan bermain permainan tradisional. Narasumber pertama yang memberikan informasi adalah Ibu Elis Siti Mahmudah,S.Pd yang merupakan guru wali kelas V. Beliau mengutarakan proses belajar mengajar dan penggunaan media pembelajaran yaitu sebagai berikut: “...Kelas 5 masih KTSP neng, bisanya pertama mengkondisikan anak terlebih dahulu, baru ke pembeljaran. Jadi pemberlajarannya biasa aja neng soalnya kelas 5 mah belum K-13. Kalo ada media ya media, kan tidak semua pembelajaran menggunakan media jadi intinya yah kita menyesuaikan dengan materi aja neng". Selanjutnya Ibu Sumi,S.Pd menuturkan bagaimana peran permainan tradisional dalam mengembangkan berbagai kecerdasan, khususnya kecerdasan emosional. Berikut penuturannya: “...Penting neng karena dalam permainan tersebut nak bisa dilatih untuk bekerja sama, yang mungkin jika anaknya pendiam dengan bermain permainan tradisional sedikitsedikit melatih dia untuk bekerja sama dengan orang lain agar punya motivasi dan dia tidak merasa sendiri”. Berdasarkan hasil wawancara di atas dengan narasumber bernama Ibu Sumi,S.Pd yang merupakan guru wali kelas I, dapat di jelaskan bahwa dalam proses pembelajaran beliau menerapkan pembelajaran PAIKEM, untuk permainan tradisional sendiri di kelas I masih jarang dan belum terlalu di perkenalkan lebih jauh. Peran permainan tradisional sangat penting dalam mengembangkan kecerdasan emosional karena jika ada anak yang pendiam setidaknya dengan bermain permainan tradisional melatih untuk bekerja sama. Secara keseluruhan dari hasil penelitian melalui wawancara dengan beberapa narasumber, maka dapat di jelaskan bahwa hampir semua guru mengimplementasikan permainan tradisional dalam permbelajaran tertentu, dan para guru juga mengakui peran permainan tradisional sangat penting dalam mengembangkan berbagai perkembangan kecerdasan anak, terutama dalam perkembangan kecerdasan emosional anak Ternyata kecerdasan seseorang tidak hanya di dapat melalui belajar di dalam kelas saja namun bisa melalui dengan cara bermain, dengan bermain anak akan mengungkapkan persaanya, mengekspresikan emosinya. Permainan tradisional mengandung banyak sekali nilai-nilai tertentu yang bersifat edukasi. Jadi permainan tradisional bisa dijadikan suatu media pembelajaran agar pembelajaran menjadi menyenangkan, di samping itu ada banyak manfaat yang bisa didapat dari bermain permainan tradisional yaitu untuk meningkatkan kecerdasan salah satunya yaitu kecerdasan emosional.

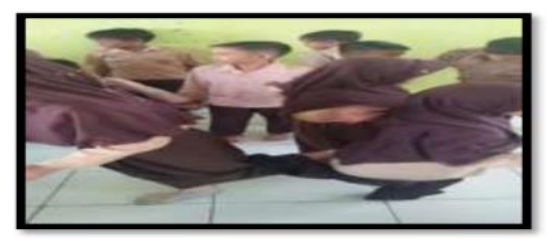

Gambar 2. Kegiatan Permainan Tradisional

Salah satu contoh permainan yang di terapkan dalam pembelajaran di kelas adalah parengket-rengket jengkol yang berasal dari daerah sunda. permainan ini biasanya dilakukan anak sambil bernyanyi, hal ini bermanfaat untuk merangsang pertumbuhan anak dengan daya kreativitasnya saat menyanyikan lagu yang akan dimainkan dalam permainan ini, motorik anak dan keseimbangan anak dalam menjaga tubuhnya agar tidak terjatuh. Di situlah anak harus bisa menjalin kerjasama yang baik, karena permainan ini membutuhkan kekompakan. Secara keseluruhan dari hasil penelitian melalui wawancara dengan beberapa narasumber, maka dapat di jelaskan bahwa hampir semua guru mengimplementasikan permainan tradisional dalam permbelajaran tertentu, dan para guru juga mengakui peran permainan tradisional sangat penting dalam mengembangkan berbagai perkembangan kecerdasan anak, terutama dalam perkembangan kecerdasan emosional anak Ternyata kecerdasan seseorang tidak hanya 


\section{Jurnal Lensa Pendas, Vol. 5 Nomor 2 , Tahun 2020, Hlm 8 - 14}

Widia Indah Lestari ${ }^{1}$, Nunu Nurfirdaus ${ }^{2}$

di dapat melalui belajar di dalam kelas saja namun bisa melalui dengan cara bermain, dengan bermain anak akan mengungkapkan persaanya, mengekspresikan emosinya. Permainan tradisional mengandung banyak sekali nilai-nilai tertentu yang bersifat edukasi. Jadi permainan tradisional bisa dijadikan suatu media pembelajaran agar pembelajaran menjadi menyenangkan, di samping itu ada banyak manfaat yang bisa didapat dari bermain permainan tradisional yaitu untuk meningkatkan kecerdasan salah satunya yaitu kecerdasan emosional. Hal ini senada dengan yang di ungkapkan oleh Bangsawan (2019:3-8) bahwa ada beberapa manfaat dari permainan tradisional yaitu, (1) belajar sportivitas, (2) mengasah kecerdasan, (3) sosialisasi lebih banyak, (4) mampu bekerja sama, (5) belajar mengelola emosi, (6) meningkatkan kepercayaan diri, (7) anak saling menghargai, (8) bersikap demokratis, (9) anak lebih aktif, (10) mengajarkan tanggung jawab.

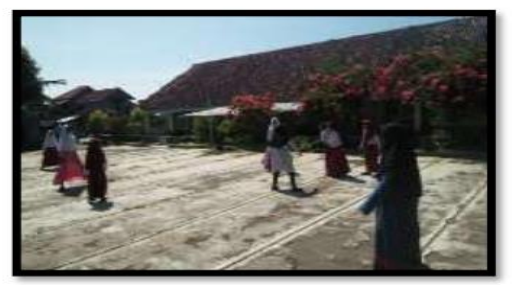

Gambar 3. Kegiatan Permainan

Tradisional

Gambar di atas adalah salah satu contoh permainan tradisional gobag sodor yang dilakukan oleh siswa dan siswi saat jam istirahat ini. Permainan tradisional gobang sodor ini harus memiliki dua grup berbeda, dimana masing-masing tim biasanya terdiri dari 3 atau 5 orangatau lebih. Intinya adalah antar tim saling menghadang secara bergantian agar yang menjadi lawan tidak bisa lolos dalam melewati garis-garis pembatas hingga bolak-balik. Agar bisa memenangkan permainan ini jangan ada yng terkena tangkap penjaga, dan semua lawan harus selamat selama proses bolak-balik dalam area garis yang sudah di tentukan. Berdasarkan paparan di atas maka dapat disimpulkan bahwa permainan ini sifatnya berkelompok dan harus memiliki kerja sama yang baik agar mencapai kemenangan. Tujuan dari permainan ini adalah agar anak mampu membuat strategi, melatih kejujuran, melatih ketangkasan, kesabaran dan menjadikan anak memiliki pribadi yang tidak egois.

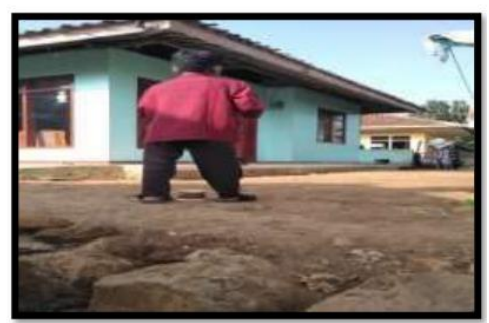

\section{Gambar 4. Kegiatan Bermain}

Layang-layang

Gambar diatas merupakan salah satu contoh anak sedang bermain permainan tradisional layang-layang. Layang-layang merupakan lembaran bahan tipis berkerangka yang diterbangkan ke udara dan terhubungkan dengan tali ataubenang ke daratan atau pengendali. Bermain layanglayang sangat membutuhkan kesabaran di saat menari angin agar layanglayang bisa terbang. Senada dengan paparan di atas bahwasanya ada salah seorang ahli yaitu Misbach dalam Safrudin dkk (2014:2), dimana ia mengatakan bahwa permainan tradisional telah lahir sejak ribuan tahun yang lalu, hasil dari proses kebudayaan manusia zaman dahulu yang masih kental dengan nilai-nilai kearifan lokal. Meskipun sudah sangat tua, ternyata permainan tradisional memiliki peran edukasi yang sangat manusiawi bagi proses belajar seorang individu, terutama anak-anak. Dikatakan demikian, karena secara alamiah permainan tradisional mampu menstimulasi berbagai aspek-aspek perkembangan anak yaitu: motorik, kognitif, emosi, bahasa, sosial, spiritual, ekologis, dan nilainilai/moral. Berdasarkan data yang diperoleh dari narasumber saat melakukan wawancara maka peneliti dapat menarik kesimpulan bahwa permainan tradisional mampu memberikan dampak positif terhadap siswa. Meskipun tidak semua siswa menyukai dan tau permainan tradisional, setidaknya dengan di implementasikan 


\section{Jurnal Lensa Pendas, Vol. 5 Nomor 2 , Tahun 2020, Hlm 8 - 14}

Widia Indah Lestari ${ }^{1}$, Nunu Nurfirdaus ${ }^{2}$

dalam pembelajaran akan menambah wawasan mereka tentang permainan jaman dulu. Berdasarkan hal tersebut maka dapat di ketahui bahwa anak yang menyukai permainan tradisional akan cenderung memiliki sikap yang baik, suka menolong, sabar, tidak egois, jujur, bertanggung jawab, mampu mengelola emosi, pandai bersosialisasi. Berbeda hal nya dengan anak yang tidak menyukai permainan tradisional dia cenderung egois, suka berbuat gaduh dan jahil, kurang peduli, membeda-bedakan teman dalam bermain. Mengenai hal diatas maka dapat disimpulkan bahwa permainan tradisional mampu mengembangkan kecerdasan emosional anak.

\section{SIMPULAN}

Pada bagian ini berikan pernyataan bahwa apa yang diharapkan, sebagaimana dinyatakan pada bab "Pendahuluan" pada akhirnya dapat menghasilkan bab "Hasil dan Pembahasan", sehingga ada kesesuaian. Selain itu juga dapat ditambahkan harapan pengembangan hasil penelitian dan penerapan harapan studi lanjut ke tahap selanjutnya (berdasarkan hasil dan pembahasan).

Berdasarkan hasil temuan data yang diperoleh dari bebrpa informan yang telah di paparkan dalam pembahasan, dapat disimpulkan: 1. Permainan tradisional di SD Negeri 2 Kalapgunung sudah di terapkan di sekolah melalui berbagai kegiaatan seperti dalam kegiatan belajar mengajar, kegiatan ekstrakurikuler, istirahat atau pun dalam kegiatan non formal. Permainan tradisional dapat dikatakan sudah menjadi suatu keharusan dan sudah menjadi salah satu program dasr yang sudah di jalankan di sekolah tersebut, hal ini dikarenakan memang diakui oleh kepala sekolah serta guruguru bahwa permainan tradisional dapat mengembangkan berbagai keterampilan dan kecerdasan anak, salah satunya kecerdasan emosional. Kecerdasan emosional siswa dan siswi di SD Negeri 2 Kalapgunung ini cukup bervariatif. 2. Implemntasi perminan tadisional dalam mengembangkan kecerdasan emosional bahwa perminan tradisional mempengaruhi kecerdasan emosional siswa. Siswa yang cenderung menyukai permainan tradisional akan cenderung memiliki sikap yang baik, suka menolong, sabar, tidak egois, jujur, bertanggung jawab, mampu mengelola emosi, pandai bersosialisasi. Berbeda hal nya dengan anak yang tidak menyukai permainan tradisional dia cenderung egois, suka berbuat gaduh dan jahil, kurang peduli, membedabedakan teman dalam bermain.

\section{DAFTAR PUSTAKA}

Ahmadi, Rulam. 2016. Metode Penelitian Kualitatif. Yogyakarta: AR-RUZZ MEDIA.

Andriani, Tuti. 2012. Permainan Tradisional dalam Membentuk Karakter Anak Usia Dini. Ejurnal.uin-suska.id. Jurnal Sosial Budaya Vol 9 (1).

Moleong. 2007. Metodologi Penelitian Kualitatif. Bandung: PT Remaja Rosdakarya.

Safrudin, dkk. 2014. Aktualisasi Pembeljaran Berbasis Permainan Tradisional Sebagai Upaya Mengembangkan IQ, EQ dan SQ Siwa dalam Mewujudkan Karakter Bangsa Yang Berbudaya. Media.neliti.com. Jurnal PENA. Vol 1 (2).

Sugiyono. 2015. Metode Penelitian Pendidikan. Bandung: ALFABETA. 